\title{
The Implementation of Astronomy as a Teaching- Learning Tool for High School Students in Manaus
}

\author{
Ingrid Celeste Silva Costa \\ Physics Student in the Physics Department at the \\ Universidade Federal do Amazonas, Manaus-Amazonas \\ Brazil, ingrid.celeste.silva@gmail.com
}

\author{
Luis Ricardo Pereira Lima \\ Physics Student in the Physics Department at the \\ Universidade Federal do Amazonas, Manaus-Amazonas \\ Brazil, luis.r1.pereira@gmail.com \\ Igor Tavares Padilha \\ Professor in the Physics Department at the Universidade \\ Federal do Amazonas, Manaus-Amazonas Brazil, \\ igorfis@ufam.edu.br
}

\begin{abstract}
Brazil is a country with low emphasis in astronomy education in the Public Educational System. At a very early age, students of the Public Education System have a very poorly introduction in science, the teachers are badly equipped to teach and the problems in our system lead to low qualified professionals and an aversion to science in general. Our work aimed to teach, encourage and inspire high school students that lived and studied at slums and low-income neighborhoods to put science in their lives through astronomy classes and also try to multiply the amount of people that can multiply that knowledge through the world.

We went to some schools that really needed support and started a weekly basis class with students that wanted to learn astronomy as they did not have that kind of class growing up. As the classes progressed, the students seemed more interested with the classes at school and more willing to learn what was being taught at school, and as a result they were more inclined to join our University and start learning more about Engineering, Astrophysics, Programing and more. We aim with this work to start a new era of Education in our country were science has a stronger focus in young students, and in the process, creating people that can help build a new, better and well-structured country.
\end{abstract}

\section{Keywords-Atronomy, science, school, education, student}

\section{INTRODUCTION}

For many high school students, physics is the worst nightmarish subject, full of equations to memorize and hard to solve questions. To the teacher is up the difficult task to unravel this science and bring it to the classroom, in a diversified and interesting way. Seeking to ease this problem, a Project was developed with the proposal of inserting activities involving Astronomy in high school, that because of its multidisciplinary character, is shown a useful tool to the teachers that intend to captivate and motivate their students.
Due to the Fact that Astronomy is not a discipline in the Brazilian school curriculum, we have to work with astronomy teaching informally [1], by introducing activities related to their subjects inside classes of other disciplines as a way to complement the proposed knowledge. So, the activities of this Project will be developed with First Year High School students.

\section{Methodology}

We believe that the Astronomy teaching must be presented side by side with the technological advancements incorporated with the scientific breakthroughs that are being discovered at the Research Centers [2]. Although, the knowledge produced at the Research Centers and Universities need to go through a didactic transposition that further the comprehension of the students. As the main method to the progress of the proposed activities, we used the Method of Didactic Transposition of Yves Chevallard [3].

By separating two classes, one canonic (which will receive traditional Physics classes) and a pilot one (that will receive an intervention), we are interested to see the effectiveness of the insertion of astronomy teaching as a motivating agent for teaching-learning of science for students in the first year of High School. For that, we take as a theoretical framework the subjects of Mechanics and Kinematics, and had been thought of in a sequence of 6 lessons divided into 2 main moments.

In the first moment we will propose a moment of conversation with the students in order to grasp their perceptions about Physics and its importance for the comprehension and development of Society. Then, through a lecture (using slides and projector, or, in their absence, putting together a line of ideas on the board) students will be introduced to some ideas about the origin of movements studying quick points on the history of astronomy. After that, we will start effectively the study of some movements like uniform rectilinear motion and uniformly variable movement. A time will also be reserved for the resolution of proposed exercises in the classroom. 
In a second moment, we will present Newton's laws of motion, those expositions will aid them to get used to physical phenomena in our planet and try to quantify the same. Aiming to provide a more playful moment, a practical activity on assembly and rocket launching made from recyclable material was proposed, thus bringing not only a moment of teacher-student interaction, but also an applicability of the contents studied in the second didactic moment.

Finally, the effectiveness of the activities was assessed by means of questionnaires, group activities and discourse analysis, where reports were collected during specific classes [4].

\section{FINAL RESULTS}

It was explained that the first didactic moment we would implement as a initial part of the cinematics content, and, after that, there would be a break in the implementation for the students to prepare with necessary subjects to continue with the implementation of the project. However, the teacher that was assigned to us missed a lot of classes he was supposed to give and it delayed our job that was supposed to be done in 4 weeks to 7 weeks.

In Mid-April the teachers from the State Network from Manaus declared a strike that prolonged to the end of May, delaying our job in more than one month, totalizing 12 weeks of delay in our application.

During some classes, a couple of students started to harass Celeste moaning at her and proclaiming some very disrespectful words, this made her feel unsafe at the facility and we took the issue to the Principal of the school, they searched for the students that did this and punished the appropriated way so that we could go back to work.

At the end of the activities, the student's engagement and their morale became evident. Some of them commented that they would like to follow some of the science careers in engineering, physics and other subjects. Due to their socioeconomic reality, these careers are, in their minds, something impossible and unreachable and the project was proven satisfactory in such scope.

\section{CONCLUSION}

In the implementation process of this project, the students' desire to a differentiated and more comprehensive education. Even though it was not possible to apply of the proposal in its entirety at the school, students are still looking for us to ask when will be the next astronomy class and this is nothing but a yearning on the part of students to see a current and applicable science in their classroom [5] However, in this process, the active participation of the teacher as mediator is essential. this knowledge to create a mutual sharing environment, where science teaching is not only seen by its technical and scientific terms but also be recognized as part of human construction and its relations with the human social, cultural, economic and political context around us. [6]. Due to the socioeconomic reality of the students, our presence there was a decisive point in their lives, so that they can choose a career that suits them and give them and their families a better life.

\section{REFERENCES}

[1] LANGHI, R.; NARD, R. Ensino da Astronomia no Brasil: educação formal, informal, não formal e divulgação cientifica. Bauru, São Paulo, Universidade Estadual Paulista. v. 31, n. 4, 4402. P. 02-09, Mar./Mai./Jun./Fer. 2009-2010.

[2] PEIXOTO, D.E ; KLEINKE, M.U . Expectativa de estudantes sobre a astronomia no ensino médio - Revista Latino-Americana de Educação em Astronomia - RELEA, n. 22, p. 21-34, 201616

[3] CHEVALLARD, Y. La transposición didáctica: del saber sábio al saber enseñado. Argentina: La Pensée Sauvage, 1991.

[4] CERVO, A. L.; BERVIAN, P. A. SILVA, M. Metodologia científica. 6. ed. São Paulo: Prentice Hall, 2007.

[5] PEIXOTO, D.; KLEINKE, M. Expectativas De Estudantes Sobre A Astronomia No Ensino Médio - Revista Latino-Americana de Educação Em Astronomia

[6] DAmASCENO, J. O Ensino De Astronomia Como Facilitador Nos Processos De Ensino E Aprendizagem - UNIVERSIDADE FEDERAL DO RIO GRANDE 